$[\mathrm{MK}]$

\title{
Heat flow, hydrothermal circulation and basalt intrusions in the Guaymas Basin, Gulf of California
}

\author{
A.T. Fisher ${ }^{a}$ and K. Becker ${ }^{b}$ \\ “ Ocean Drilling Program, Texas A\&M University, I000 Discovery Drive, College Station, TX 77845, USA \\ "Rosenstiel School of Marine and Atmospheric Science, University of Miami, 4600 Rickenbacker Causeway, Miami, FL 33149, USA
}

Received November 6, 1989; revised version accepted November 19, 1990

\section{ABSTRACT}

\begin{abstract}
The Guaymas Basin is part of an en echelon series of short, seafloor-spreading segments in the Gulf of California. The basin is separated from adjacent deeps by long, northwest-southeast-striking transform faults, and divided into subparallel. northern and southern troughs which trend northeast to southwest. Rapid sedimentation ( 1 to $5 \mathrm{~m} \mathrm{ka}^{-1}$ ) results in a striking morphological contrast between seafloor spreading in the Guaymas Basin and that in more mature, mid-ocean settings. Basalt does not extrude onto the seafloor in the basin as flows and pillows, but instead intrudes into a thick sediment layer. The presence of relatively unconsolidated sediments lining the floor of the basin make this setting ideal for the study of axial heat flow and the thermal budget of oceanic crustal formation.

Thermal data delineate several modes of heat transfer in both troughs of the basin, with negligible heat flow in some areas and values greater than $3 \mathrm{~W} \mathrm{~m} \mathrm{~m}^{-2}$ in others. Broad heat flow highs, several square kilometers in area, result from a combination of deep, conductive heat flow, slow, intergranular fluid circulation and vigorous hydrothermal venting. Areas of low heat flow between heat-flow highs and near normal faults which bound the basin may be indicative of hydrothermal recharge. The geometry of faults, shallow sills and broad northeast-southwest structural trends in the basin largely seems to govern the distribution of heat flow. The highest values are clustered within a few isolated zones in each trough, with a total area of about $30 \mathrm{~km}^{2}$. Variations in heat flow of two orders of magnitude occur over distances as small as a few hundred meters. Fourteen hydrothermal vents in the southern trough of the Guaymas Basin have been sampled directly, and found to have temperatures in excess of $250^{\circ} \mathrm{C}$. Locally, conductive heat flow at the seafloor is significantly raised in the vicinity of these vents, but the general pattern appears to require more deeply seated, conductive heat sources. The mean heat flow in the southern trough is $453 \pm 342$ (s.d.) $\mathrm{mW} \mathrm{m}^{-2}$. A simple analysis of the heat budget in the southern trough suggests that the total intruded section between the top of the magma chamber and the seafloor may be unusually thin, perhaps only several hundred meters in thickness.
\end{abstract}

\section{Introduction: sedimented spreading centers}

Thermo-tectonic models of rifting include several phases during the formation of new ocean basins. Whether accomplished primarily through pure shear [1], simple shear [2], or some combination of these two endmembers [3], the transition from continental rifting to seafloor spreading is complex and may last several Ma to several tens of Ma. This complexity may increase when rapid sedimentation accompanies rifting [4], a condition apparent today in the central Gulf of California $[5,6]$ and along portions of the Juan de Fuca and Gorda Ridges [7,8]. Because the early stages of rifting are buried at most mature, passive margins, geologists must often look to conceptual models and modern analogs of ancient rifts to understand their evolution (e.g., $[9,10])$.

The Juan de Fuca and Gorda Ridges are relatively mature, having separated the Pacific and Farallon Plates millions of years prior to nearing the western North American subduction zone [11]. In contrast, portions of the northern and central Gulf of California are making the initial transition from continental rifting to seafloor spreading while under the direct influence of rapid sedimentation [1]. The Guaymas Basin in the central Gulf of California receives 1 to $5 \mathrm{~m} \mathrm{ka}^{-1}$ of mixed terrigenous, siliceous and calcareous sediment [12,13], precluding the formation of typical oceanic crust 
[14]. As anomalous as the Guaymas Basin may appear in comparison to more mature mid-ocean spreading centers, however, it could exemplify early stages of rifting stages at many heavily sedimented, passive margins (e.g., $[9,4,15]$ ).

In the next sections, heat flow data from the Guaymas Basin, collected on $1980 \mathrm{R} / \mathrm{V}$ Melville and $1985 \mathrm{R} / \mathrm{V}$ Atlantis II/Alvin, cruises are combined with results from other surveys to delineate the complicated thermal conditions apparent in this setting. These observations provide compelling evidence for the existence of several distinct hydrothermal systems within the sediments and crust of a young rift. We have attempted to separate discrete contributions to total heat flow in a portion of the Guaymas Basin, including conductive and advective components resulting from hydrothermal venting, in order to elucidate relationships between tectonic style, crustal structure, heat flow, and hydrothermal activity. Numerical modeling studies were also completed to simulate hydrothermal circulation resulting from basalt intrusion within a thick sediment layer; these results are discussed in a companion paper [16].

\section{Geological and geophysical setting}

The Gulf of California (Fig. 1) is composed of a series of northeast-southwest-trending deeps, the bathymetric expressions of seafloor-spreading centers [17]. These short troughs, generally offset from each other by much longer, northwestsoutheast oriented transform faults $[18,19]$, collectively provide a transition from extension on the East Pacific Rise (EPR) to the south, to rightlateral slip along the San Andreas Fault system to the north [20,13]. Magnetic anomalies in the southern gulf along the Mazatlan Ridge and south of the Tamayo Fracture Zone [17,9] suggest a full spreading rate between peninsula Baja and the Mexican mainland of $49 \mathrm{~mm} \mathrm{a}^{-1}$ [21] to $58 \mathrm{~mm}$ $\mathrm{a}^{-1}[17,18]$ over the last several million years.

\subsection{Southern and northern troughs}

The Guaymas Basin (Fig. 1) contains subparallel, northern and southern troughs (extensional grabens), each 50 to $150 \mathrm{~m}$ deeper than the surrounding ocean floor, offset from each other by about $20 \mathrm{~km}[19,6,13]$. The diatomaceous nannofossil ooze and clastic-rich turbidites pouring into

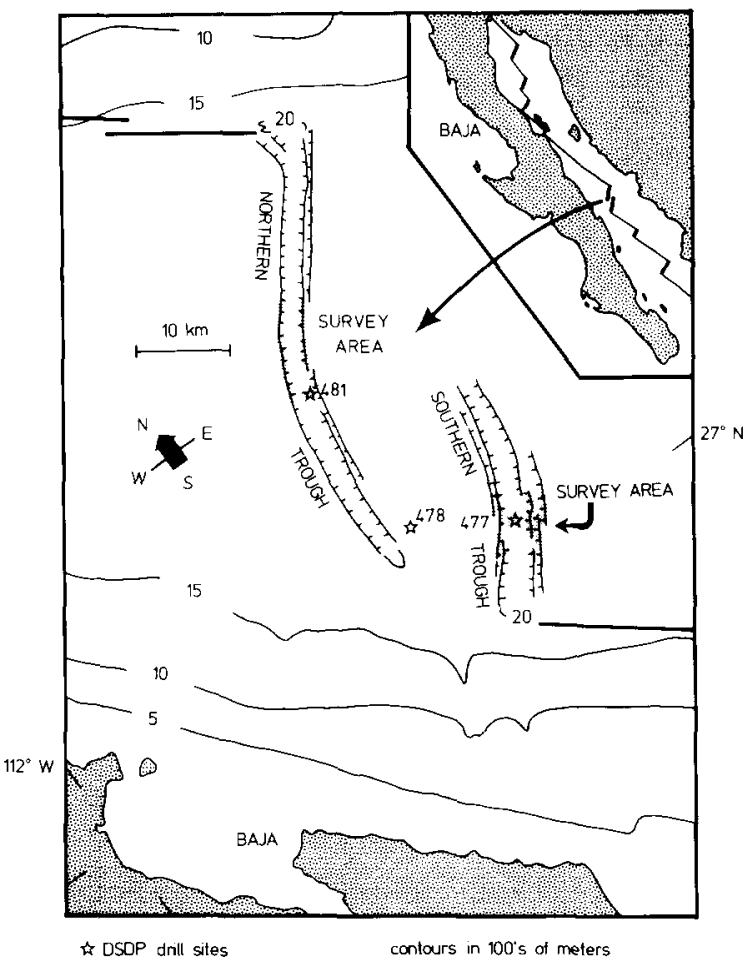

Fig. 1. Index map showing location of the Guaymas Basin in the central Gulf of California, study areas in the northern and southern troughs, and locations of DSDP drill sites [24].

the two troughs [12,22] keep bottom topography smooth. The uppermost sediments form an acoustically transparent layer 50 to $100 \mathrm{~m}$ thick which becomes thinner near the northern trough/ southern trough transition [23], while older sediments become acoustically opaque with depth [24].

The southern trough (Fig. 1) is about $30 \mathrm{~km}$ long and 2 to $4 \mathrm{~km}$ wide, is partially overlapped by the northern trough to the northwest, and is asymmetric in bathymetric expression and tectonic fabric. The northern trough is about $40 \mathrm{~km}$ long, and varies in width from 2 to $3 \mathrm{~km}$. The northwest walls of both troughs rise along single faults to the surrounding basin floor while the southeast trough margins are composed of a series of smaller-throw, normal faults which step up more gradually to the adjacent seafloor. The floors of the troughs are not completely flat, but are broken by a series of $\leq 1 \mathrm{~km}^{2}$ intra-rift hills which rise up to $100 \mathrm{~m}$ above the surrounding terrain. These hills are concentrated in both the northern and southern troughs near bends in the rift valleys [24] where 
the two troughs apparently overlap, perhaps indicating the axial extent of the neovolcanic zones. The interiors of these hills are acoustically incoherent, although their complete sediment cover indicates that they predate the latest turbidite deposition [24].

\subsection{Crustal structure}

Sedimentation is so rapid in the Guaymas Basin that it prevents extrusion of fresh basalt onto the seafloor. Instead, hot magma penetrates crust, previous intrusions and indurated sediments, rises to a level where melt pressure exceeds lithostatic pressure plus sediment tensile strength, and spreads laterally [25]. The newly accreted material solidifies as intercalated sills within the thick sediments $[14,22]$. This unusual sedimentary environment has prevented the formation of a typical ridge axis (e.g., [26]), easily discernable magnetic anomalies $[27,28]$ or oceanic crust of normal structure or thickness $[19,13,4]$.

Moore [19] presented a model of the Guaymas Basin with an oceanic crust 7 to $8 \mathrm{~km}$ thick resulting from compensation of the thick sediments. This model was largely based on the work of Phillips [29], whose interpretation of seismic structure was made prior to elucidation of basin structure and tectonics. In contrast, a multi-channel seismic line across the southern trough near Deep Sea Drilling Project (DSDP) Site 477 [13] revealed a strong reflector, suggesting both the minimal sediment thickness and the presence of an axial magma chamber, at a depth of only about 700-1000 m [24]. DSDP Leg 64 drilled to a maximum depth of $424 \mathrm{~m}$ [13], revealing doleritic sills alternating with porous, hemipelagic sediments [22]. The Leg 64 scientists noted an abrupt decrease in sediment porosity next to the shallow sills indicating expulsion of pore water and a reduction in thickness of the sedimentary layers of the same magnitude as the thickness of the intruding basalts $[14,25]$ leaving the seafloor essentially flat.

\section{Thermal studies}

The smooth seafloor and thick, unlithified surface sediments make the Guaymas Basin an ideal site for the study of axial heat-flow variations, allowing easy penetration of thermal probes and piston core barrels. Thermal conductivity is $0.68-73 \mathrm{~W} \mathrm{~m}^{-1} \mathrm{~K}^{-1}$ throughout the shallow sediments in the basin [23,24]. All pre-1980 heat-flow surveys in the Guaymas Basin were radar and satellite navigated with a precision of $\pm 300-500$ $\mathrm{m}$, inadequate for mapping the detailed heat-flow variations necessary to delineate complicated hydrothermal circulation patterns. Later expeditions, including DSDP Leg 64, utilized transponder navigation with $\pm 20-40 \mathrm{~m}$ accuracy.

The high sedimentation rate in the basin may reduce measured heat flow at the seafloor by 10 to $30 \%[30,31]$, but as recent, shallow intrusions could easily overwhelm this process, and the specific timing of intrusions and vigorous hydrothermal cycling in the basin are unknown, there is no sedimentation correction applied to the data presented here. Conductive heat flow may actually be moderately higher than that measured, but since variations of one order of magnitude are common over a few hundred meters, this uncertainty should not be critical to the following analyses.

\subsection{Characteristics of heat flow in the southern and northern troughs}

A deep-tow survey in 1980 followed by a DSR/V Alvin dive program in 1982 provided 172 transponder-navigated heat-flow measurements, most in the northern trough [23] and 30 along a single transect in the southern trough [24]. A 1985 Atlantis II/Alvin survey of the southern trough added 91 additional measurements [32], bringing the total to 128 over a roughly 4 by $8 \mathrm{~km}$ area (Fig. 2). Detailed reviews of previous heat-flow studies in the Guaymas Basin are presented elsewhere $[5,23,33]$.

On a broad scale, the heat-flow distribution in both troughs follows structural trends, with regions of both high and low values running subparallel to trough-bounding and trough-center faults. On a smaller scale, there are complicated variations, with differences $>1 \mathrm{~W} \mathrm{~m}^{-2}$ over just a few hundred meters. Heat flow is highest near hydrothermal vents, which were easily identified directly from Alvin and on side-scan sonar records as sulfide chimneys and clusters of tube worms and other biota [24]. Background heat flow in the southern trough is about $650 \mathrm{~mW} \mathrm{~m}^{-2}$ through the central floor and near $180 \mathrm{~mW} \mathrm{~m}^{-2}$ in the surrounding area, with the highest values 


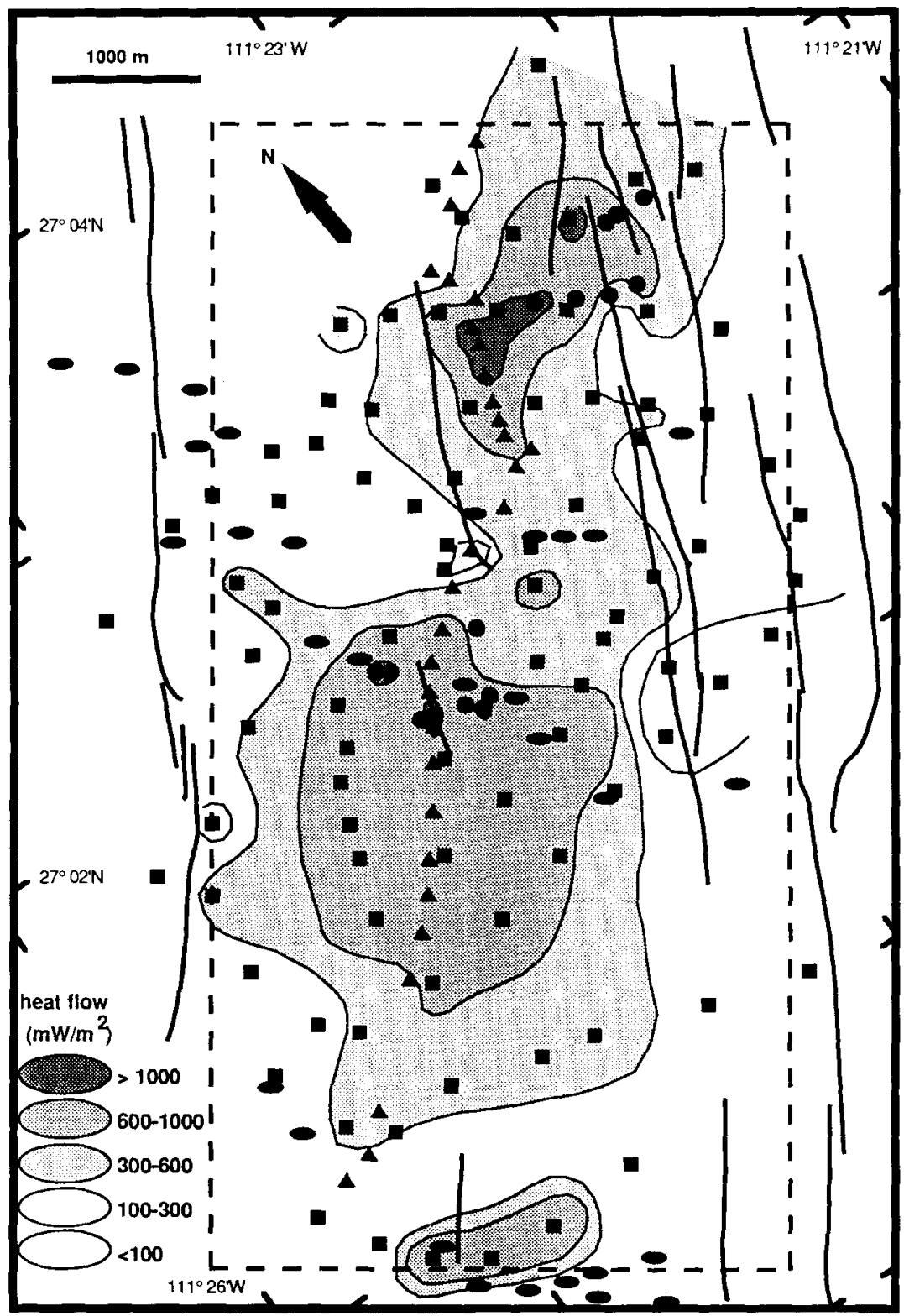

Fig. 2. Contoured heat flow and locations of all heat-flow measurements in the southern trough. Triangles are multi-penetration (Pogo) measurements from Lonsdale and Becker [24]; circles are Alvin measurements from the same source; squares are Pogo measurements from a 1985 Atlantis II survey [31,32,33]. These measurements were all transponder navigated $\pm 20-40 \mathrm{~m}$. Ovals are earlier measurements $[58,5]$ positioned $\pm 300-500 \mathrm{~m}$. Thick lines are normal faults [24], shown in greater detail in Fig. 6 . Dashed box outlines 4 by $8 \mathrm{~km}$ area within which there are 128, well-navigated heat-flow measurements. Contours were drawn by hand, using only transponder-navigated measurements.

concentrated over the shallowly buried northern, central and southern sills [24,33]. A measurement of $0 \mathrm{~mW} \mathrm{~m} \mathrm{~m}^{-2}$ (no resolvable change in temperature with depth along the length of a $2-\mathrm{m}$ thermistor probe) near a trough-center fault north of the central sill (Fig. 2), and other low values as well, may be indicative of hydrothermal recharge [23,32]. Measurements of extremely low heat flow near normal faults (Fig. 2) suggest that at least some of the cold, fluid recharge supporting high- 
temperature hydrothermal circulation may be fault-directed.

There is a 2 by $6 \mathrm{~km}$ region in the central portion of the southern trough with heat flow $\geq 300 \mathrm{~mW} \mathrm{~m}^{-2}$ (Fig. 2). One small and two larger areas delineate heat flow $\geq 600 \mathrm{~mW} \mathrm{~m}^{-2}$, covering a total of $3 \mathrm{~km}^{2}$ over shallow sills. The northern-most heat flow high also overlaps subparallel normal faults which are buried beneath surface sediments (Fig. 2). The extent of this region beyond the detailed survey area to the north is unknown. The central heat flow high contains a superimposed $1 \mathrm{~km}^{2}$ zone with heat flow $\geq 1000$ $\mathrm{mW} \mathrm{m}^{-2}$, and several black smoker vents with temperatures in excess of $300^{\circ} \mathrm{C}$. The southernmost zone of elevated heat flow is smaller, $<0.5$ $\mathrm{km}^{2}$, and appears to be associated with a fault which cuts along strike in the central portion of trough (Fig. 2).

Fig. 3 illustrates the locations of hydrothermal deposits, plumes, and vents either sampled directly or identified from side-scan sonar in the southern trough ([24]; A. Campbell, pers. commun.), along with the highest, well-navigated heat-flow values. Although sediment temperatures and conductive heat flow are clearly raised immediately adjacent to hydrothermal vents, the exact relationship between heat flow and venting is not obvious. Many hydrothermal deposits and plumes are located in regions of only moderate heat flow (Figs. 2 and 3). It will be demonstrated later that the broad heat-flow highs in the central trough can not be attributed solely to the presence of high-temperature vents, but require the presence of conductive, possibly transient, heat sources.

Heat-flow data were averaged in $128,2.5 \times 10^{5}$ $\mathrm{m}^{2}$ squares $\left(500 \times 500 \mathrm{~m}\right.$, total $\left.32 \mathrm{~km}^{2}\right)$ in the southern trough field area, yielding a mean of $453 \pm 324$ (s.d.) $\mathrm{mW} \mathrm{m}^{-2}$. A histogram of these average values (Fig. 4) indicates that fully one half of the survey area has heat flow less than $400 \mathrm{~mW}$ $\mathrm{m}^{-2}$, although this observation is not immediately apparent from examination of the unevenly distributed data (Fig. 2). The total heat output measured thus far in the southern trough field area, estimated by numerically integrating beneath a contour map based on the same data used to construct the histogram in Fig. 4 , is about $1.5 \times 10^{7}$ $\mathrm{W}$. This total includes the contribution due to conductive cooling within several hundred meters of active hydrothermal vents.

Heat-flow data from the northern trough [5,23] are more sparsely distributed than those in the southern trough (Fig. 5). Heat flow appears to be lower overall than in the southern trough, with the highest values located near the trough center, including four values in excess of $2 \mathrm{~W} \mathrm{~m}^{-2}$. Zones with heat flow $\geq 300 \mathrm{~mW} \mathrm{~m}^{-2}$ are smaller and more isolated here than in the southern trough, covering only about $3 \mathrm{~km}^{2}$ in total. Areas of extremely low heat flow near the northwest trough wall and near the southern end of the survey area may indicate fluid recharge.

Fluid recharge and discharge (Darcy) velocities through sediments in both troughs were estimated by fitting nonlinear thermal gradients (as measured with a $2-\mathrm{m}$, outrigger probe) to a one-dimensional model of conductive and advective heat transfer [34]. This method is more effective for estimating discharge than recharge, as recharge induces the greatest curvature in the thermal gradient at the base of the convecting layer, beyond the reach of a short thermistor probe. These estimates are presented along with simple geological interpretations of the southern and northern troughs in Fig. $6[23,24,32]$. Fluid flow through shallow sediments at velocities of 1 to $15 \times 10^{-8}$ $\mathrm{m} \mathrm{s}^{-1}\left(0.3\right.$ to $\left.4.8 \mathrm{~m} \mathrm{a}^{-1}\right)$ is widespread in both troughs and may indicate shallow circulation [24] and slow cooling of intrusions (following an initially more rapid phase), as suggested by numerical analyses [16]. This relatively low-temperature, low-velocity flow (with temperatures near that of surrounding sediments, and velocities up to several meters per year) is distinct from high-temperature, high-velocity flow through hydrothermal vents. Fig. 6 also indicates the locations of $4-\mathrm{kHz}$ deeptow profiles across both troughs onto which nearby heat-flow values have been projected along structural strike (Figs. 7 and 8). Several southern trough profiles, originally presented without heat-flow data in Lonsdale and Becker [24], have been extended and supplemented with additional data from the 1985 Atlantis II survey.

Profile $A-A^{\prime}-A^{\prime \prime}$ from the southern trough clearly illustrate that the highest heat-flow values are located in the central trough, adjacent to the intra-rift hills (Fig. 7). There is also a general correlation between apparent faults located below 


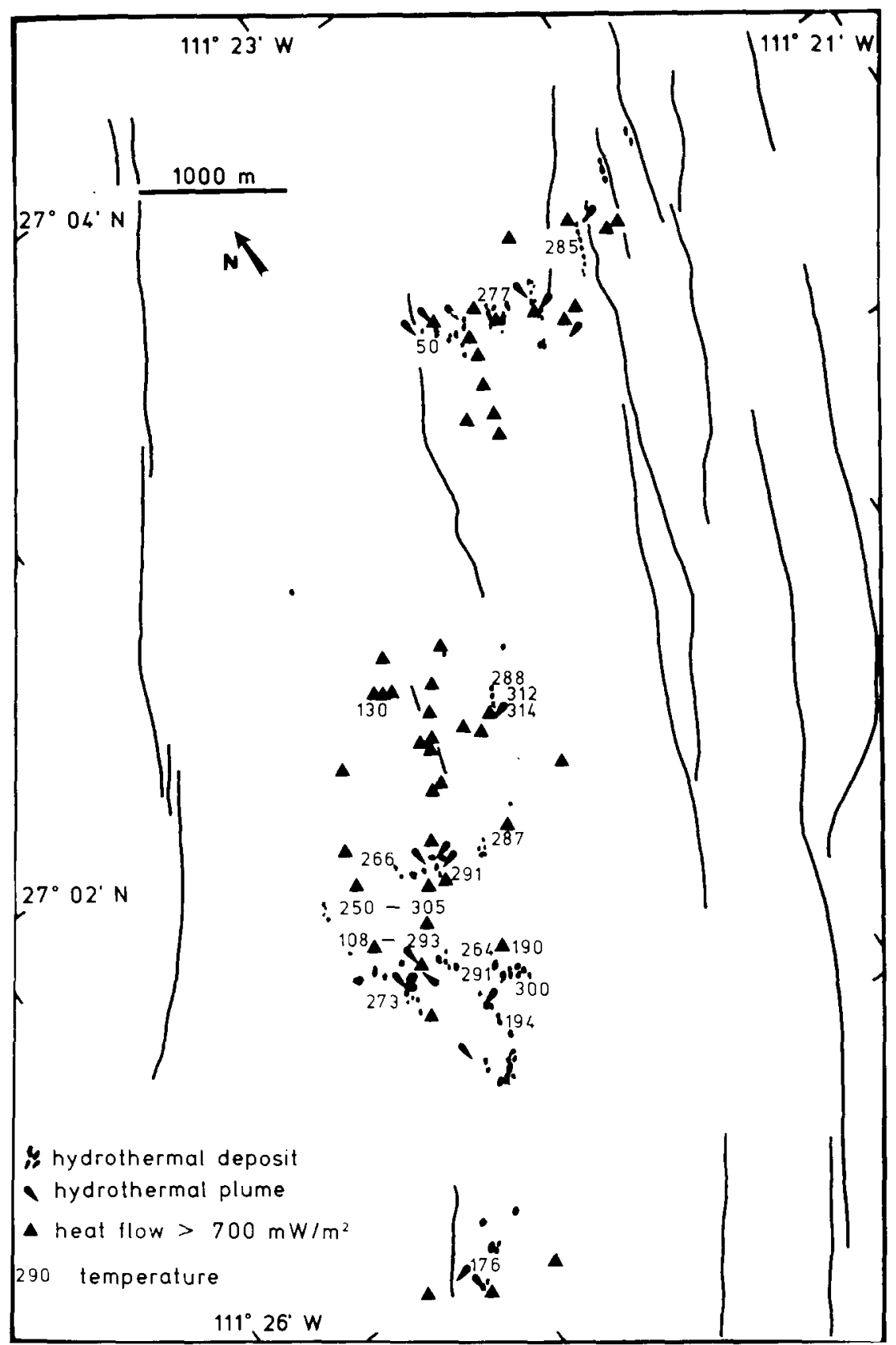

Fig. 3. Locations of hydrothermal deposits and plumes detected by deep tow and from Alvin [24], well-navigated heat-flow measurements greater than $700 \mathrm{~mW} \mathrm{~m}^{-2}$ and the temperatures of vents (in ${ }^{\circ} \mathrm{C}$ ) measured from Alvin ([24]; A. Campbell, pers. commun.) in the southern trough.

the sediment surface and slow fluid upflow through the sediment column, as estimated from curved thermal gradients (Profiles D-D'-D" and E-E'$\left.E^{\prime \prime}\right)$. In these last two profiles, the highest heatflow values are also located directly over the north sill (Figs. 6a and 7). A single profile along strike in the southern trough, $F-F^{\prime}$, confirms that heat flow is highest over the north and central sills, and of ten associated with recent hydrothermal activity.

The relationship between hills, sills and heat 


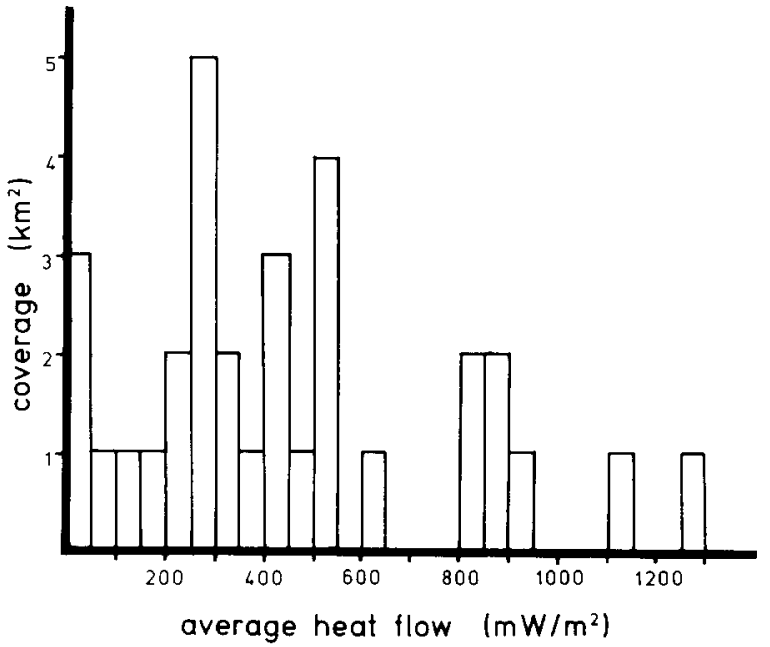

Fig. 4. Histogram of averaged heat flow data from the southern trough, from $321 \mathrm{~km}^{2}$ squares. The mean is $453 \pm 324$ (s.d.) $\mathrm{mW} \mathrm{m} \mathrm{m}^{-2}$.

flow is less distinct in the northern trough (Fig. 8). Some high values are located off the side of hills (profiles D-D' and E- $\mathrm{E}^{\prime}$ ) although other values near $1500 \mathrm{~mW} \mathrm{~m}^{-2}$ are found directly over small hills in the central trough. The floor of the northern half of the northern trough is consistently rougher than that in the southern trough; heat flow here does not appear to correlate well with relief (profile $\mathbf{H}-\mathbf{H}^{\prime}$ ), although the uneven surface may result from recent sediment mass-wasting.

\subsection{Hydrothermal circulation in the Guaymas}

\section{Basin}

The first estimates of vent temperatures in the southern trough came from hydrothermal deposits and indicated precipitation temperatures near $280^{\circ} \mathrm{C}$ [6], and later direct measurements of vent fluids yielded temperatures from a few tens to $>300^{\circ} \mathrm{C}[24,35]$. While high-temperature vent discharge may dominate heat loss in the southern trough today, venting should be ephemeral $[5,24,36,37]$, with short periods of activity (perhaps corresponding to magma freezing) alternating with longer periods of hydrothermal quiescence (during magma chamber growth and replenishment).

Kastner [22] and Gieskes et al. [25] suggested that there are two distinct hydrothermal systems active in the Guaymas Basin: a shallow, lower temperature $\left(<150-200^{\circ} \mathrm{C}\right)$ system driven by sill emplacement and pore water expulsion, and a deeper, higher temperature $\left(>300^{\circ} \mathrm{C}\right)$ system associated with a large intrusion or axial magma chamber. The first of these systems is presumably short lived, perhaps lasting only a few years, as the mechanical emplacement of molten basalt should be a rapid process. The second system should be longer lived and thus more open to recharge [22]. Lonsdale and Becker [24] found no direct evidence of these two distinct hydrothermal systems in the southern trough (they apparently observed surface manifestations of only the higher-temperature, longer-lived venting) but inferred the existence of a third system, the sluggish convection of fluids in surface sediments above recent intrusions.

Despite abundant evidence for past vent activ-

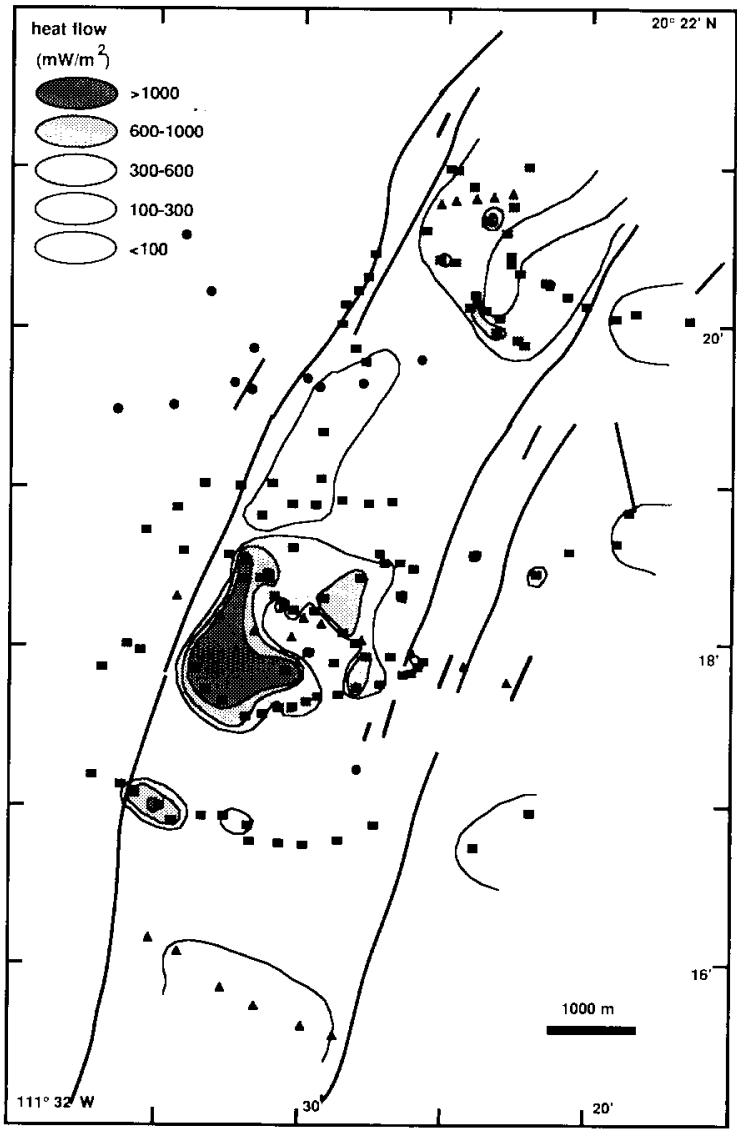

Fig. 5. Contoured heat flow and locations of all measurements in the northern trough of the Guaymas Basin. Triangles [23] from the "La Paz" survey are positioned to $\pm 20-40 \mathrm{~m}$. Squares are instrument locations from Williams et al. [59] and circles are ship locations from the same survey, all positioned to $\pm 300-500 \mathrm{~m}$. Contours were drawn by hand, using only the transponder-navigated data. 

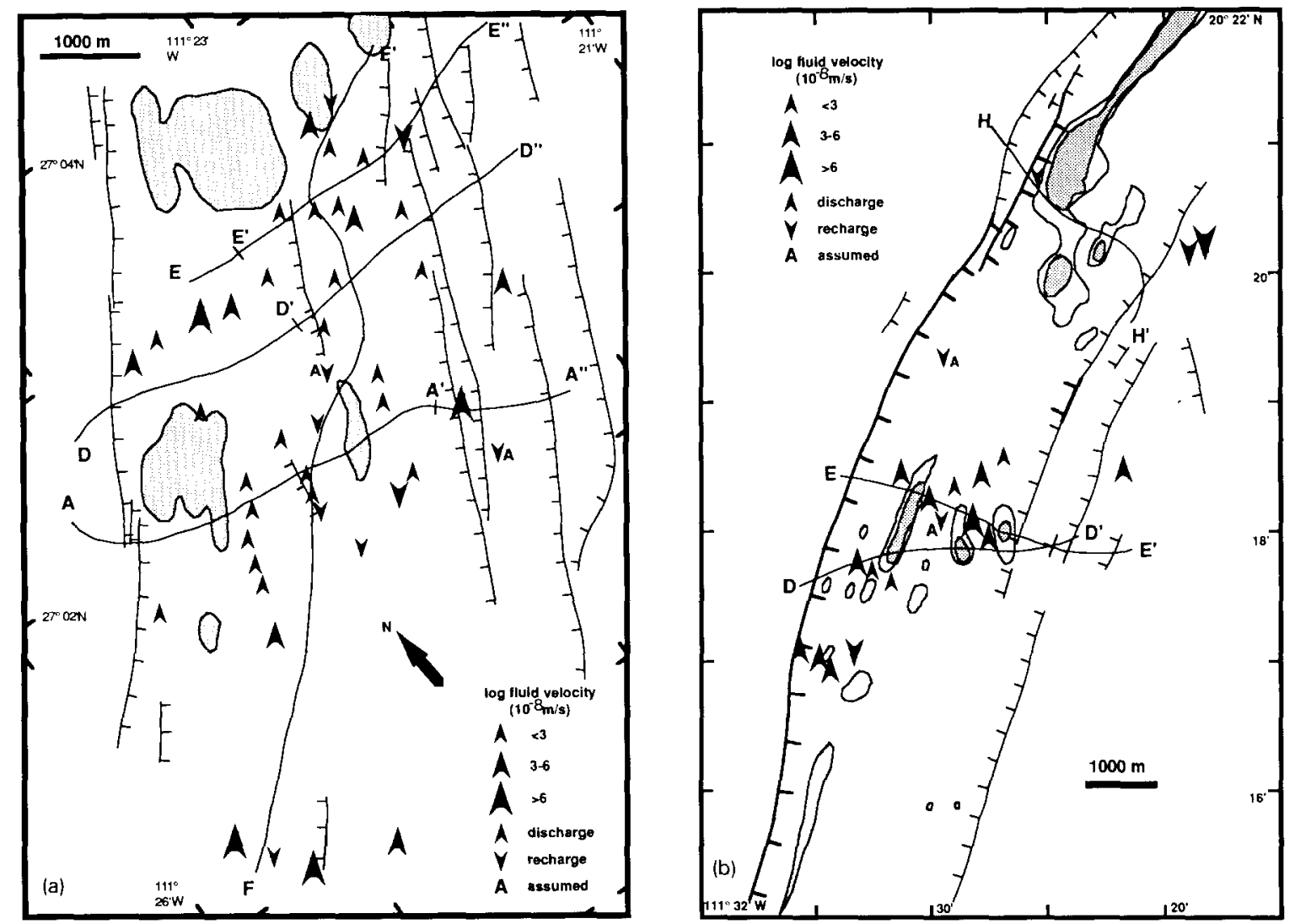

Fig. 6. (a) General geology of the southern trough [24] and results of a one dimensional advective heat flow model [23,32]. Heat-flow profiles along deep-tow lines [24] ( $A-A^{\prime}-A^{\prime \prime}, D-D^{\prime}-D^{\prime \prime}, E-E^{\prime}-E^{\prime \prime}$, and $F-F^{\prime}$ ) are shown in Fig. 7. The shaded areas are hills with relief $\leq 100 \mathrm{~m}$. (b) General geology of the northern trough and results of a one dimensional advective heat-flow model [23]. Thin lines indicate faults with displacement $>50 \mathrm{~m}$; thick lines indicate displacement $>50 \mathrm{~m}$ Lightly shaded regions are hills with relief $<50 \mathrm{~m}$; darkly shaded regions are hills with relief $>50 \mathrm{~m}$. Heat-flow profiles along deep-tow lines [23] $\left(D-D^{\prime}, E-E^{\prime}\right.$, and $H-H^{\prime}$ ) are shown in Fig. 8. Arrows indicate modeled Darcy velocities of fluids through shallow sediments, either discharge or recharge, in units of $10^{-8} \mathrm{~m} \mathrm{~s}^{-1}$.

ity and recent intrusions in the northern trough $[5,38]$ no hydrothermal plumes have been identified there as yet, even with comprehensive, deeptow surveys $[30,24]$. This observation is in strong contrast to the 20 hydrothermal plumes and 120 sites containing mineral deposits on the floor of the southern trough (Fig. 4; [24]). Overall, the northern trough appears to be cooler and hydrothermally less active today than the southern trough [5], as if the two regions are experiencing different phases of a magmatic cycle. Shallow intrusions in the northern trough appear to be closer to the rift boundary faults than are their counterparts in the southern trough [23], perhaps because brittle extension during a period of low magma supply has shifted sills intruded near the central trough towards the trough boundaries. This last interpretation would require that the two troughs be magmatically autonomous, with hightemperature hydrothermal activity in each supported by distinct magma sources.

\subsection{Conductive heat flow near active vents}

High-temperature venting influences heat loss both directly, by discharging hot fluids, and indirectly, by raising conductive heat flow immediately around vent sites [34,24]. A single $300^{\circ} \mathrm{C}$ vent discharging at $1-2 \mathrm{~m} \mathrm{~s}^{-1}$ through an $80 \mathrm{~cm}^{2}$ opening on the EPR [37,54] has a heat output approximately equal to the total observed conductive heat output of the southern trough field area. As fourteen vents have been identified in this area 

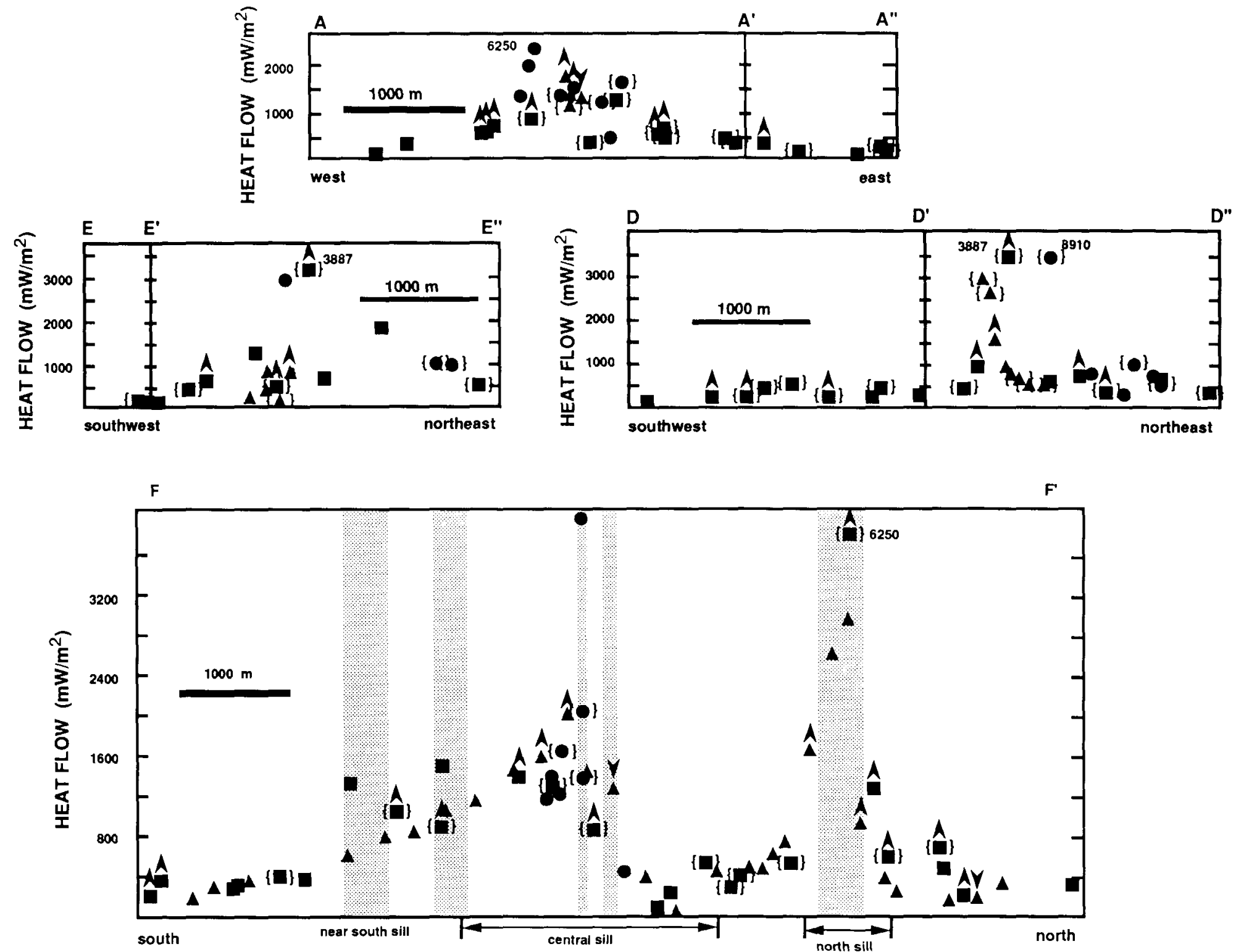

Fig. 7. Heat-flow profiles from the southern trough. Bracketed values are from within $500 \mathrm{~m}$ along structural strike of the profile; other values are from within $250 \mathrm{~m}$. Arrowheads indicate inferred fluid-flow direction, but not velocity. Profile locations are shown in Fig. 6a, along with inferred fluid velocities. 

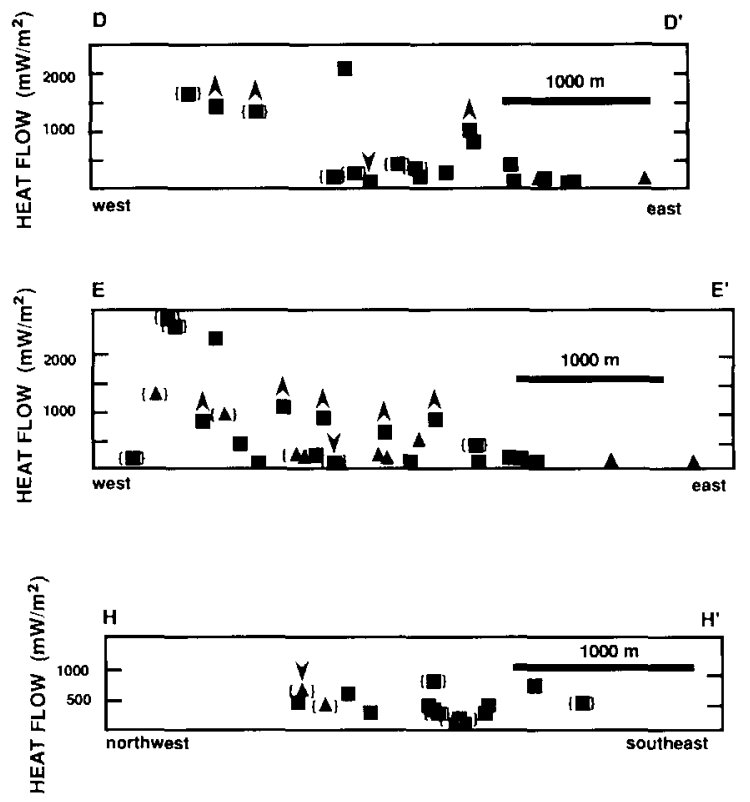

Fig. 8. Heat-flow profiles from the northern trough. Notation is the same as in Fig. 7. Profile locations and inferred fluid velocities are shown in Fig. 6b.

thus far with exit temperatures $\geq 250^{\circ} \mathrm{C}[24,35]$; A. Campbell, pers. commun.], less than $10 \%$ of the present heat loss in this region is conductive.

We have attempted to separate the conductive heat output that results directly from venting from the background heat flowing through the floor of the southern trough, to constrain the thermal state of both young intrusions within, and any crust beneath, the sediment layer. We assume that heat flow in the southern trough can be separated into two primary components (following the Kastner [22] and Gieskes et al. [25] models of hydrothermal circulation in this setting): background heat flow, originating from long-lived, deeply seated sources, and shallow heat flow, shorter-lived and originating at shallower depths. The steady-state excess, conductive heat output, $q_{e}$, due to a hydrothermal vent idealized as a constant temperature, tubular pipe oriented vertically through the seafloor (a semi-infinite, half-space), is approximately [34]:

$q_{\mathrm{e}}=\frac{4 k T_{\mathrm{w}}}{\pi r} \ln \frac{z_{\mathrm{f}}}{\pi a}$

where $k$ is the thermal conductivity of the medium, $T_{\mathrm{w}}$ the temperature of venting fluid (assumed to rise adiabatically from depth), $z_{\mathrm{f}}$ is depth of fluid origin, $r$ is the distance from the vent, and $a$ is pipe (vent) radius. As this is a steady-state treatment, it is necessary to establish the length-scale over which it is valid. Lonsdale and Becker [24] noted, after several measurements of thermal gradients in shallow sediments surrounding a single black smoker, that the $1 / r$ relationship between heat flow and distance may hold to approximately $120 \mathrm{~m}$. Assuming that the general time scale $\tau$ of a transient thermal process may be determined as a function of distance from the source $r$ and thermal diffusivity $\kappa$, as $\tau=r^{2} / \kappa$, we calculate that for the relationship defined in equation (1) to apply over a distance of $120 \mathrm{~m}$, a venting time scale on the order of at least $10^{3} \mathrm{yr}$ is required.

Several hydrothermal sites in the southern trough have been active for at least the past ten years, with little change in geochemical signature [35]. While individual vents on medium-rate spreading centers may be active for decades, complete hydrothermal systems may be active for $10^{4}-10^{5}$ yr $[39,40]$. In an effort to establish the maximum possible influence of hydrothermal venting on conductive heat flow in the southern trough of the Guaymas Basin, equation (1) was applied to calculate $q_{\mathrm{e}}$ within $500 \mathrm{~m}$ of each vent identified in the southern trough in which fluid 
temperatures have been measured ([24,35]; A. Campbell, pers commun.]. As it requires that individual vents have acted as continuous heat sources for $8 \times 10^{4} \mathrm{yr}$, approxImately as long as there has been a southern trough, this analysis will provide an upper limit to the conductive heat-flow contribution due to the vents identified thus far. In cases where several vents are located within $200 \mathrm{~m}$ of each other, it was assumed that they are fed by a single conduit containing fluid at a temperature equal to the mean of those measured in the cluster. First the contribution to conductive heat flow $q_{\mathrm{c}}$, due to each vent within $500 \mathrm{~m}$ of each heat flow measurement was calculated. These contributions were then summed, $\sum q_{\mathrm{e}}$, and subtracted from measured heat flow $q_{i}$, to produce a data set of residual heat flow $q_{\mathrm{r}}$. In cases where $\sum q_{\mathrm{e}} \geqslant q_{\mathrm{i}}$, meaning that the entire heat flow at a particular site could be attributed to nearby vents, $q_{\mathrm{r}}$ was assumed to be $0 \mathrm{~mW} \mathrm{~m}^{-2}$.

An examination of residual heat flow in the southern trough (Fig. 9) suggests that only a small portion of the broad heat flow anomaly in the center of the southern trough was removed through this exercise, despite the steady-state assumption. In addition, estimates of vertical fluid advection

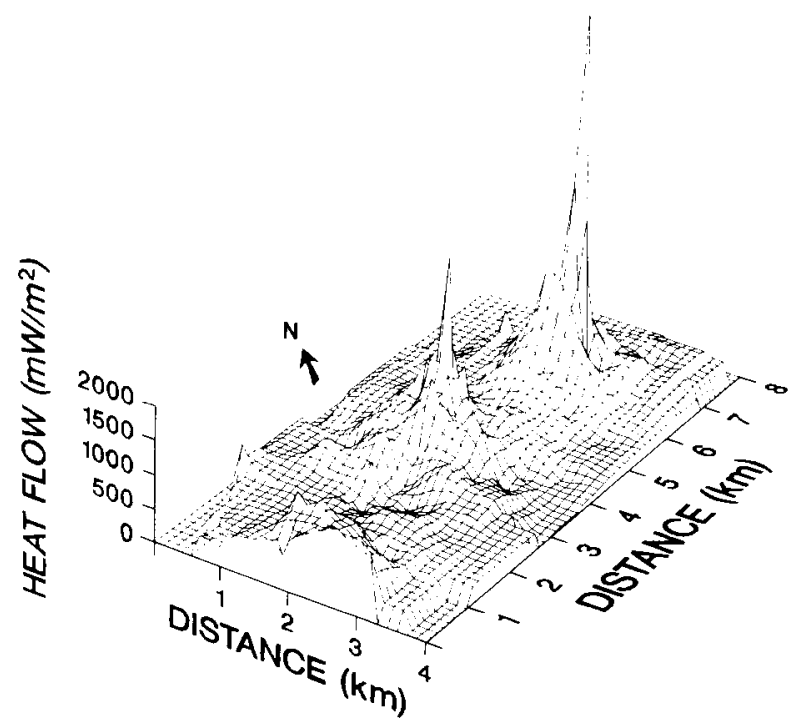

Fig. 9. Residual heat flow in the southern trough, calculated by subtracting the estimated conductive influence of hydrothermal vents. The perspective diagram was generated from 128 unevenly scattered values in the 4 by $8 \mathrm{~km}$ field area shown in Fig. 2. The central heat flow high has been somewhat reduced in extent through this exercise, but the broad anomaly remains. based on nonlinear thermal gradients (Fig. 6a) predict intergranular velocities generally less than $10^{-7} \mathrm{~m} \mathrm{~s}^{-1}$, incapable of supporting the broad heat-flow highs apparent in the southern trough, given the background conductive heat flow (Fig. 2). While there could be additional hydrothermal vents whose temperatures have not been measured (the inclusion of which would have reduced the residual heat flow calculated above), the magnitude, position and extent of the heat-flow high in the southern trough (Fig. 9) suggests that it must result from a large, conductive source, and not from localized venting.

\section{Crustal formation and the heat budget in the southern trough}

The steady-state heat output expected to result from crustal formation at a spreading center is approximately $[41,42]$ :

$H=\rho D_{\mathrm{i}} S v_{\mathrm{p}}\left(\Delta T c_{\mathrm{h}}+L\right)$

where $\rho$ is the density of the intruded rock, $D_{1}$ is the thickness of the intruded layer, $S$ is spreading center strike length, $v_{\mathrm{p}}$ is the full spreading rate, $\Delta T$ is the mean temperature drop as the magma cools from a molten to solid state, $c_{\mathrm{b}}$ is the specific heat capacity of the rock and $L$ is the latent heat released during solidification. Estimated values for several of these parameters in the southern trough field area are listed in Table 1. In the following analysis we will first assume that the intruded layer consists of all solid, igneous material between the magma chamber and the sea floor, including the sills which intrude soft sediments.

Equation (2) is applied in several ways to constrain the crustal structure in the southern trough. First the thickness of the oceanic crust in this region is estimated from seismic studies. The heat associated with the formation of this crust is then compared to thermal observations and the heat output of cooling intrusions and black smoker vents. The heat output predicted by equation (2) is also compared to the estimated output from other spreading centers with similar spreading rates. While we initially assume that basalt intrusion and crustal formation is at steady state, these processes are most likely transient at a medium-rate spreading center $[39,43]$. However, as heat output should 
TABLE 1

Parameters used to estimate expected heat output from intrusion solidification

\begin{tabular}{ll}
\hline Parameter & Value \\
\hline$\rho \quad$ density & $2900 \mathrm{~kg} \mathrm{~m}^{-3}$ \\
$S \quad$ strike length & $8 \mathrm{~km}$ \\
$v_{\mathrm{p}} \quad$ full spreading rate & $55 \mathrm{~mm} \mathrm{a}^{-1}$ \\
$\Delta T \quad$ mean temperature drop & $800^{\circ} \mathrm{C}$ \\
$c_{\mathrm{b}} \quad$ basalt heat capacity & $1300 \mathrm{~J} \mathrm{~kg}^{-1}{ }^{\circ} \mathrm{C}^{-1}$ \\
$L \quad$ latent heat & $400 \mathrm{~kJ} \mathrm{~kg}^{-1}$ \\
\hline
\end{tabular}

near a peak during periods of hydrothermal venting, the steady-state assumption inherent in equation (2) should provide an upper bound to total intrusion thickness.

Phillips [29] suggested that anomalously thick crust $(7-10 \mathrm{~km})$ underlies the Guaymas Basin, but his seismic refraction study of the Gulf of California included lines over then unknown structure and lithology which might have led to misinterpretation [13] attributed thick oceanic crust in the central Gulf of California to clastic compensation, a response to tremendous sedimentary input, and presented a model of the Guaymas Basin with 7-8 $\mathrm{km}$ thick crust. Goff et al. [44] calculated that the depth extent of seismic slip during a 31 May 1974 earthquake on the oceanic-continental transform fault offsetting the Guaymas and Carmen Basins (just south of the southern trough), indicated a centroid depth of $0-10 \mathrm{~km}$ beneath the seafloor. No sediment layer was included in their seismic velocity structure of the oceanic crust, although seismic layer 2 was assumed to be $6.0 \mathrm{~km}$ thick. Unconsolidated sediments (as are present in the southern trough) would have caused the centroid depth to be underestimated by the actual sediment thickness [44], at least several hundred meters. An 18 November 1963 earthquake just north of the Delphen Basin in the northern Gulf of California inverted to a centroid depth of $7 \pm 2 \mathrm{~km}$. The crustal thickness in the Guaymas Basin is clearly not well constrained by these studies, but as a starting point, a value of several kilometers does not seem inappropriate.

A total crustal thickness $1-6 \mathrm{~km}$ would result in heat output in the $4 \times 8 \mathrm{~km}$ southern trough study area of about $5 \times 10^{7}$ to $4 \times 10^{8} \mathrm{~W}$ (Fig.
10). The measured heat output in this area (combining conductive and porous flow convective components) is only about $1.5 \times 10^{7} \mathrm{~W}$, equal to the heat output of a single $300^{\circ} \mathrm{C}$ vent (as discussed earlier). This is probably a good assessment of the current heat loss (exclusive of that heat released directly through hydrothermal vents) as (1) this area has been extensively surveyed, and (2) numerical studies suggest that the vast majority of the heat released by intrusions in a sediment spreaded center should travel vertically through the seafloor [16]. An $2.2 \mathrm{~km}$ thick intruded layer is needed to provide enough heat to supply fourteen vents with fluid temperatures of $250^{\circ} \mathrm{C}$, plus the currently observed heat flow at steady state; this possibility requires that most of the heat can be efficiently transferred from the intruded layer to isolated hydrothermal conduits. The presence of a magma chamber at a depth of 700-1000 m $[13,45,24]$ overlain by intercalated basalt intrusions and sediments $[22,25]$, would limit total intrusion thickness to $\leq 500 \mathrm{~m}$. The maximum heat output in the southern trough resulting from solidification of a $500-\mathrm{m}$ intrusive layer would be about $3 \times 10^{7} \mathrm{~W}$ at steady state (Fig. 10 ), sufficient to

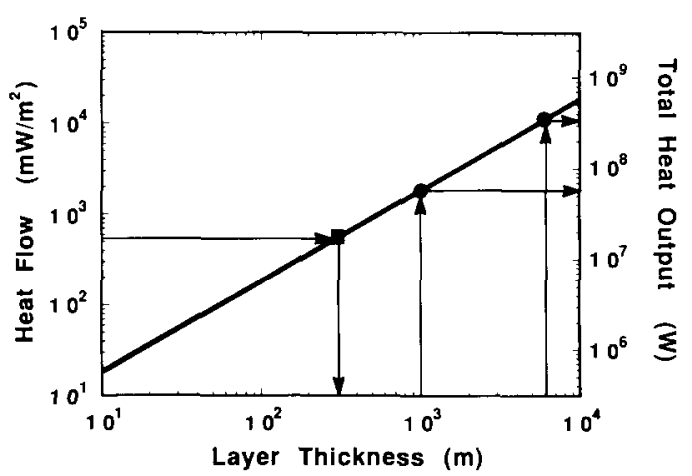

Fig. 10. The expected heat flow and total heat output in the $4 \times 8 \mathrm{~km}$ field area in the southern trough of the Guaymas Basin resulting from solidification and cooling of an intruded layer, assuming a full spreading rate of $55 \mathrm{~mm} \mathrm{a}^{-1}$. An intruded layer 1-6 km thick (between the circles) would result in total heat output of $5.0 \times 10^{7} \mathrm{~W}$ to $3.5 \times 10^{8} \mathrm{~W}$. In comparison, average heat flow of about $450 \mathrm{~mW} \mathrm{~m}^{-2}$ (square), as measured in the southern trough field area today, results in total heat output of $1.5 \times 10^{7} \mathrm{~W}$ and requires an intruded layer only about $200 \mathrm{~m}$ thick. This is also the approximate heat output of a $300^{\circ} \mathrm{C}$ hydrothermal vent with $80 \mathrm{~cm}^{2}$ opening flowing at $1-2 \mathrm{~m} \mathrm{~s}^{-1}$. 
feed only one or two high-temperature vents on top of the documented heat flow, but insufficient to drive a high-temperature vent field (e.g., [46]).

As a variation on this conceptual model, we may assume that lower intrusive layers are cooled with $100 \%$ efficiency directly by high-temperature venting, while the remaining conductive heat output in the southern trough results from solidification of shallower intrusions, including those within the sediments. This interpretation presumes that either the cooling of an axial magma chamber through venting results in the formation of massive and layered cumulates, seismic layer 3 of the oceanic crust $[36,47]$, or that venting results from direct cooling of the upper mantle beneath anomalously structured crust [4]. The assumption that a magma chamber is cooled directly by convecting fluids should provide an upper bound on the estimated thickness of the intruded layer above, since the heat released by hydrothermal vents would be cooling a heat source distinct from the intruded layer. This upper bound will probably be somewhat extreme as at least some portion of the heat flowing through the seafloor in the central portion of the southern trough would probably be conducted through the roof of the magma chamber (i.e., direct cooling of a magma chamber by hydrothermal fluids would not be $100 \%$ efficient [47]).

With average heat flow in the southern trough near $450 \mathrm{~mW} \mathrm{~m}^{-2}$, the steady-state thickness of the intruded layer would be just $200 \mathrm{~m}$ (Fig. 10). Considering that drilling on DSDP Leg 64 included penetration of about $100 \mathrm{~m}$ of basalt intrusions within the sediment layer at Site 478 [13], the remaining intrusive layer would be very thin indeed. The typical thickness of basaltic flows and dikes (seismic layer 2) elsewhere in the oceanic

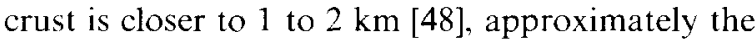
same as the depth to magma chambers imaged seismically beneath the EPR (e.g., [49]). In contrast to the seismic studies and conceptual models cited earlier, which suggested that the crust beneath the Guaymas Basin may be unusually thick, the model above includes an upper crust beneath the southern trough which is extremely thin.

During times when the magma chamber is active, it may be vigorously convecting and require periodic replenishment (e.g., [50]). The heat released during convection in a magma chamber has been estimated to be between 7.5 and $12.5 \mathrm{~W} \mathrm{~m}^{-2}$ $[50,47]$. A magma chamber beneath the southern trough with an upper surface area of 3 to $4 \mathrm{~km}^{2}$ [24] to $24 \mathrm{~km}^{2}$ (a maximum, assuming that a $3 \mathrm{~km}$ wide chamber extends the length of the southern trough survey area) could supply enough heat $\left(2.25 \times 10^{7}\right.$ to $\left.3.00 \times 10^{8} \mathrm{~W}\right)$ to continuously drive two to eighteen high-temperature vents.

Were there 20 hydrothermal vents presently active (a reasonable upper bound) in the southern trough field area with fluid exit temperatures of $300^{\circ} \mathrm{C}$, then the total heat output would be about $3 \times 10^{8} \mathrm{~W}$, over a ridge length of $8 \mathrm{~km}$, or about $4 \times 10^{7} \mathrm{~W} \mathrm{~km}^{-1}$ of ridge. In comparison, Crane et al. [51) used several simple geometric models to estimate the heat output along a $160-\mathrm{km}$ section of the Juan de Fuca Ridge (spreading rate: 5.5 to 6.0 $\mathrm{cm} \mathrm{a}^{-1}$ ) from thermal anomalies in the water column near the ridge crest. Their line source model of vent heat sources yielded an estimate of 2.9 to $11.3 \times 10^{7} \mathrm{~W} \mathrm{~km}^{-1}$ of ridge, in good agreement with the calculation above.

Normalized by the spreading rate, the heat released by $500 \mathrm{~m}$ of cooling and solidifying intrusions is about $2 \times 10^{12} \mathrm{~J} / \mathrm{m}^{2}$, about the same as the conductive component predicted to escape from the Juan de Fuca ridge by Morton and Sleep [52]. This value is considerably lower than the $14 \times 10^{12} \mathrm{~J} / \mathrm{m}^{2}$ used in the crustal spreading model of Wilson et al. [53], which included a $6.5 \mathrm{~km}$ thick crustal section, a magma chamber beneath a $1.5-\mathrm{km}$ basaltic lid. and spreading rate of about 6 $\mathrm{cm} \mathrm{a}^{-1}$. The total estimated hydrothermal cooling currently accomplished by the fourteen documented hydrothermal vents in the southern trough field area is essentially the same. however, as that required by the much thicker crust and deeper magma chamber of the Wilson et al. [53] model. If this cooling rate has held since the southern trough formed, then the oceanic crust away from the magma chamber could have a more normal thickness. As an alternative model, cycles of heat flow and hydrothermal activity could be genetically linked to the same magma pulses that influence tectonic fabrics and the timing of intrusive events [54]. If an assymetric pattern of normal faulting, like that surrounding the northern and southern troughs (Fig. 2), reflects spreading during a period of low magma supply [55], then the currently observed heat flow could represent a late stage of 
transient, largely conductive, cooling of the main magma body (e.g., ref. [40]).

\section{Summary and conclusions}

Measured heat flow in the geothermally active zones in both troughs of the Guaymas Basin varies

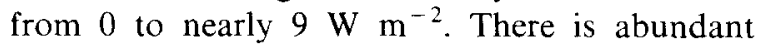
evidence for both slow, cool intergranular fluid flow at rates of meters per year in both troughs, and direct observations of vigorous hydrothermal discharge with temperatures $>300^{\circ} \mathrm{C}$ and velocities of meters per second in the southern trough. In both the northern and southern troughs, conductive heat flow is highest in the center of the axial valleys, particularly adjacent to active vents. Low temperature recharge in both troughs is inferred to exist in several isolated areas, particularly along normally faulted walls and along midgraben faults. Although conductive heat flow is highest in the immediate vicinity of hydrothermal vents, broad zones of relatively high heat flow in both troughs probably require large, conductive heat sources.

The present heat output in the southern trough could result from cooling and solidification of oceanic crust with a thickness of several kilometers, provided that there was some efficient way to redirect $>90 \%$ of the heat output to flow through isolated fluid conduits. Numerical and analytical studies suggest that it is extremely difficult to focus broad hydrothermal flow through isolated conduits in relatively impermeable sediments [16] or basalt [56]. The heat output in the southern trough seems more readily explained by (1) an intrusive layer (perhaps $\leq 500 \mathrm{~m}$ in thickness), composed of individual intrusions within the sediments plus an underlying basement of unknown structure, which provides much of the energy necessary to generate the broad regions of high, largely conductive heat flow; and (2) hydrothermal vents which tap directly into an axial magma chamber or other deep heat source.

\section{Acknowledgements}

We thank the captains, crew, and technicians of the $\mathrm{R} / \mathrm{V}$ Atlantis II, R/V Lulu and DSR/V Alvin for assistance with successful field programs in the Guaymas Basin. Support was also provided by the
U.S. Department of Energy under contract DEAC03-765F00098. This manuscript benefitted from suggestions by $T$. Stern and thoughtful reviews by N. Sleep, R. Lowell and R. von Herzen. This research was supported by NSF grants OCE79-08811, OCE 81-17557, OCE 84-15697 and OCE 85-16773, a Koczy Fellowship, administered through the University of Miami, RSMAS, and the Ocean Drilling Program.

\section{References}

1 D. Moore and J. Curray, Geologic and tectonic history of the Gulf of California, in: J. Curray, D. Moore, et al., eds., Init. Rep. D. S. D. P. 64, 1279-1298, U.S. Gov. Print. Off., Washington, D.C., 1982.

2 G.S. Lister, M.A. Etherege and P.A. Symonds, Detachment faulting and the evolution of passive margins, Geology 14 , 246-250, 1982.

3 W.R. Buck, F. Martinez, M.S. Steckler and J.R. Cochran, Thermal consequences of lithospheric extension: pure and simple, Tectonics 7, 213-234, 1988.

4 A. Nicolas, A novel type of crust produced during continental rifting, Nature 315, 112-115, 1985.

5 D. Williams, K. Becker, L. Lawver and R. Von Herzen, Heat flow at the spreading centers of the Guaymas Basin, Gulf of California, J. Geophys. Res. 84, 6757-6769, 1979.

6 P. Lonsdale and L. Lawver, Immature plate boundary zones studied with a submersible in the Gulf of California, Geol. Soc. Am. Bull. 91, 555-569, 1980.

7 C.R.B. Lister, Heat flow west of the Juan de Fuca ridge, J. Geophys. Res. 75, 2648-2654, 1970.

8 D.A. McManus, O. Weser, C.C. von der Borch, T, Vallier and R.E. Burns, Regional aspects of deep sea drilling in the northeast Pacific, in: D.A. McManus et al., Init. Rep. D. S. D. P. 5, 621-636, U.S. Gov. Print. Off., Washington, D.C., 1970 .

9 P.A. Larson, J.D. Mudie and R.L. Larson, Magnetic anomalies and fracture zone trends in the Gulf of California, Geol. Soc. Am. Bull. 83, 3361-3368, 1972.

10 M.S. Steckler, N. Lyberis, F. Berthelot and X. LePichon, Tectonic evolution of the Gulf of Suez in a regional context, Tectonophysics, 1988.

11 C.A. Williams, An oceanwide view of Paleogene plate tectonic events, Paleogeogr. Paleoclimatol. Paleoecol. 57, 3-25, 1986.

12 S.E. Calvert, Accumulation of diatomaceous silica in the sediments of the Gulf of California, Geol. Soc. Am. Bull. 77, 569-596, 1966.

13 J.R. Curray, D.G. Moore et al., Init. Rep. D. S. D. P., 64, U. S. Gov. Print. Off., Washington, D.C., 1982.

14 G. Einsele, J.M. Gieskes, J. Curray, D.M. Moore, E. Arguayo, M.-P. Aubrey, D. Fornari, J. Guerrero, M. Kastner, K. Kelts, M. Lyle, Y. Matoba, A. Molina-Cruz, J. Niemitz, J. Rueda, A. Saunders, H. Schrader, B. Simonet and V. Vaquier, Intrusions of basalt into highly porous 
sediments, and resulting hydrothermal activity, Nature 283 , $441-445,1980$

15 Z. Ben-Avraham and R. Von Herzen, Heat flow and continental breakup: The Gulf of Elat (Aqaba), J. Geophys. Res. 92, 1407-1416, 1987.

16 A.T. Fisher and T.N. Narasimhan, Numerical simulations of hydrothermal circulation resulting from basalt intrusions in a buried spreading center, Earth Planet. Sci. Lett. 103, $100-115,1990$ (this volume).

17 R.L. Larson, W.H. Menard and S.M. Smith, The Gulf of California: a result of ocean floor spreading and transform faulting, Science 161, 780, 1968.

18 T.M. Atwater, Implications of plate tectonics for the Cenozoic tectonic evolution of western North America, Geol. Soc. Am. Bull. 81, 3513-3536, 1970.

19 D.G. Moore, Plate-edge deformation and crustal growth in the Gulf of California structural province, Geol. Soc. Am. Bull. 84, 1883-1905, 1973.

$20 \mathrm{~T}$. Wilson, $A$ new class of faults and their bearing on continental drift, Nature 207, 343-347, 1965.

21 C. DeMets, R.G. Gordon, S. Stein and D.F. Argus, A revised estimate of Pacific-North American motion and implications for western North America plate boundary zone tectonics, Geophys. Res. Lett. 14, 911-914, 1987.

22 M. Kastner, Evidence for two distinct hydrothermal systems in the Guaymas Basin, in: J. Curray, D. Moore et al., Init. Rep. D. S. D. P. 64, 1143-1158, U.S. Gov. Print. Off., Washington, D.C., 1982.

$23 \mathrm{~K}$. Becker, Heat flow studies of spreading center hydrothermal processes, Ph.D. dissertation, Scripps Institute of Oceanography, 1981.

24 P. Lonsdale and K. Becker, Hydrothermal plumes, hot springs, and conductive heat flow in the southern trough of Guaymas Basin, Earth Planet. Sci. Lett. 73, 211-225, 1985.

25 I. Gieskes, M. Kastner, G. Einsele, K. Kelts and J. Niemitz, Hydrothermal activity in the Guaymas Basin, Gulf of California, a synthesis, in: J. Curray, D. Moore et al., Init. Rep. D. S. D. P. 64, 1159-1168, U.S. Gov. Print. Off., Washington, D.C., 1982.

26 K.C. MacDonald and T.M. Atwater, Evolution of rifted ocean ridges, Earth Planet Sci. Lett. 39, 317-327, 1978.

27 R.L. Larson, Bathymetry, magnetic anomalies, and plate tectonic history of the month of the Gulf of California, Geol. Soc. Am. Bull. 83, 3345-3360, 1972.

$28 \mathrm{~S}$. Levi and R. Riddihough, Why are marine magnetic anomalies suppressed over sedimented spreading centers?, Geology 14, 651-654, 1986.

29 R.P. Phillips, Seismic refraction studies in the Gulf of California, in: Marine Geology of the Gulf of California, T. Van Andel and G. Shor, eds., AAPG Mem. 3, pp. 90-121, AAPG Press, Tulsa, 1964.

30 L. Lawver and D. Williams, Heat flow in the central Gulf of California, J. Geophys. Res. 84, 3465-3478, 1979.

31 A.T. Fisher, Heat flow and hydrothermal circulation through young oceanic sediments and crust, Ph.D. Thesis, University of Miami, RSMAS, 335 pp, 1989.

32 A.T. Fisher and K. Becker, Heat flow and hydrothermal circulation in the southern trough of the Guaymas Basin, Gulf of California, EOS 68, 424 (abstract), 1987.

$33 \mathrm{~K}$. Becker and A. Fisher, A brief review of heat flow studies in the Guaymas Basin, Gulf of California, in: The Gulf and Peninsular Province of the Californias, Memoir 47, J.P. Dauphin and B.R.T. Simoneit, eds., Am. Assoc. Pet. Geol., Tulsa, in press, 1990.

34 N.H. Sleep and T. Wolery, Egress of hot water from mid ocean ridge hydrothermal systems: some thermal constraints, J. Geophys. Res. 83, 5913-5922, 1978.

35 A.C. Campbell, T.S. Bowers, C.I. Measures, K.K. Faulkner, M. Khadem and J.M. Edmond, A time series of vent fluid compositions from $21^{\circ} \mathrm{N}$, East Pacific Rise (1979. 1981, $1985)$ and the Guaymas Basin, Gulf of California (1982, 1985), J. Geophys. Res. 93, 4537-4549, 1988.

36 C.R.B. Lister, Qualitative models of spreading center processes, including hydrothermal circulation, Tectonophysics 37, 203-218, 1977.

37 K.C. Macdonald, K. Becker, F.N. Spiess and R. Ballard, Hydrothermal heat flux of the "black smoker" vents on the East Pacific Rise, Earth Planet Sci. Lett. 48, 1-7, 1980.

38 P.F. Lonsdale, J.L. Bischoff, V.M. Burns, M. Kastner and R.E. Sweeney, A high temperature hydrothermal deposit on the seabed at a Gulf of California spreading center, Earth Planet. Sci. Lett. 49, 8-20, 1980.

39 G.S. Lichtmann and J.-P. Eissen. Time and space constraints on the evolution of medium-rate spreading centers, Geology 11, 592-595, 1983.

$40 \mathrm{~T}$. Brikowski and D. Norton, Influence of magma chamber geometry on hydrothermal activity at mid-ocean ridges, Earth Planet. Sci. Lett. 93, 241-255, 1989.

41 D.P. McKenzie and J.C. Sclater, Heat flow in the eastern Pacific and seafloor spreading, Bull. Volcanol. 33, 101-118, 1969.

42 T.A. Stern, Asymmetric back-arc spreading, heat flux and structure associated with the Central Volcanic Region of New Zealand, Earth Planet. Sci. Lett, 85, 265-276, 1987.

43 E.S. Kappel and W.B.F. Ryan, Volcanic episodicity and a non-steady state rift valley along the northwest Pacific spreading centers: evidence from Sea MARC, J. Geophys. Res. 91, 13925-13940, 1986.

44 J.A. Goff, E.A. Bergman and S.C. Soloman, Earthquake source mechanisms and transform fault tectonics in the Gulf of California, J. Geophys. Res. 92, 10,485-10,510, 1987.

45 K. Kelts, Petrology of hydrothermally metamorphosed sediments at Deep Sea Drilling Project Site 477, Southern Guaymas Basin, Gulf of California, in: J. Curray, D. Moore et al., Init. Rep. D. S. D. P. 64, 1123-1136, U.S. Gov. Print. Off., Washington, D.C., 1982.

46 S.A. Little, K.D. Stolzenbach and R.P. Von Herzen, Measurements of plume flow from a hydrothermal vent field, J. Geophys. Res. 92, 2587-2596, 1987.

47 R.P. Lowell and P.A. Rona, Hydrothermal models for the generation of massive sulfide ore deposits, J. Geophys. Res. 90, 8769-8783, 1985.

48 C.G.A. Harrison and E. Bonatti, The oceanic crust, in: The Sea, C. Emiliani, ed., Vol. 7, pp. 21-47, Wiley, New York, NY, 1982.

49 R.S Detrick, P. Buhl, E. Vera, J. Mutter, J. Orcutt, J. Madsen and T. Brocher, Multi-channel seismic imaging of a crustal magma chamber along the East Pacific Rise, Nature 326, 35-41, 1987. 
50 C.R.B. Lister, On the intermittency and crystallization mechanisms of sub-seafloor magma chambers, Geophys. J. R. Astron. Soc. 73, 351-366, 1983.

51 K. Crane, F. Aikman III, R. Embley, S. Hammond, A. Malahoff and J. Lupton, The distribution of geothermal fields on the Juan de Fuca Ridge, J. Geophys. Res. 90, $727-744,1985$.

$52 \mathrm{~J}$. Morton and N. Sleep, A mid-ocean ridge thermal model: constraints on the volume of axial hydrothermal heat flux, J. Geophys. Res. 90, 11,345-11,353, 1985.

53 D.S. Wilson, D.A. Clague, N.H. Sleep and J.L. Morton, Implications of magma convection for the size and temperature of magma chambers at fast spreading ridges, J. Geophys. Res. 93, 11,974-11,984, 1988.

54 K.C. Macdonald, Mid-ocean ridges: fine-scale tectonic, volcanic and hydrothermal processes within the plate boundary zone, Annu. Rev. Earth Planet. Sci. 10, 155-190, 1982.
55 G.D. Harper, Tectonics of slow spreading mid-ocean ridges and consequences of a variable depth to the brittle/ductile transition, Tectonics 4, 395-409, 1985.

56 J.R. Cann and M.R. Strens, Modeling periodic megaplume emission by black smoker systems, J. Geophys. Res. 94 , 12,227-12,237, 1989.

57 D.R. Converse, H.D. Holland and J.M. Edmone, How rates in the axial hot springs of the East Pacific Rise $\left(21^{\circ} \mathrm{N}\right)$ : implications for the heat budget and the formation of massive sulfide deposits, Earth Planet. Sci. Lett 69, 159-175, 1984.

58 L. Lawver, D. Williams and R. Von Herzen, A major geothermal anomaly in the Gulf of California, Nature 257, 23-28, 1975.

59 D. Williams, D., Becker, L. Lawver and R. Von Herzen, Heat flow at the spreading centers of the Guaymas Basin, Gulf of California, J. Geophys. Res. 84, 6757-6769, 1979. 